\title{
COOLING GREENHOUSES BY USING SOLAR ENERGY
}

\section{S. El- soaly ${ }^{(1)}$, M. A. Shetawy $^{(1)}$, R. R. El-bessoumy ${ }^{(2)}$ G.G. Emam ${ }^{(3)}$ \\ ABSTRACT}

Two experimental greenhouses were used in this study, (G1) a greenhouse was ventilated naturally (as control) and (G2) another greenhouse was cooled by using solar energy, it contains: principally of the units: regeneration heat source (solar collector), the rotary wheel dehumidifier (The first part was the regeneration part that equals $50 \%$ of the total surface area). Two pad materials were used as pads for cooling, the used materials were cellulose and palm fiber. Three different air velocities of 1,2 and $3 \mathrm{~m} / \mathrm{s}$ were used with each pad material. Three water flow rats of 10, 15 and $20 \mathrm{~L} / \mathrm{min}$ were used on each pad. The experiments were carried out in the premises of an open roof (third floor) of a Faculty of Agriculture Engineering, Al- Azhar University, Nasr City, Cairo Egypt (Latitude angle of $30^{\circ} 02^{\prime} 30^{\prime \prime} \mathrm{N}$, Longitude angle of $31^{\circ} 14^{\prime}$ 07" E, and mean altitude above sea level of $18 \mathrm{~m}$ ). The experiments were carried out on April to July2018. The obtained results indicated that the average temperature of $31.0{ }^{\circ} \mathrm{C}$ was outside the greenhouse through all the experiments while the average temperatures of $36.4,24.5{ }^{\circ} \mathrm{C}$ were inside the greenhouses (G1), (G2), respectively. The average temperature reduction of $6.6{ }^{\circ} \mathrm{C}$ was outside and inside the cooling greenhouse by using solar energy, while the average temperature reduction of $11.9{ }^{\circ} \mathrm{C}$ was in the un cooled greenhouse. The highest cooling efficiency of $79.5 \%$ was recorded when the outside temperature of $30.6{ }^{\circ} \mathrm{C}$ and relative humidity of $41.2 \%$, the previous highest cooling efficiency was when the cellulose pad material was used at water flow rate of 20L/min and wheal face air velocity of $2 \mathrm{~m} / \mathrm{s}$.

\section{INTRODUCTION}

7 he temperature degrees during summer in Egypt reach high values. These high values are not suitable for growing certain agricultural plants in the field and make the conditions harder for the plants inside the greenhouse.

(1) Prof., Agr. Eng., Fac. of Agr. Eng., AL-Azhar Univ.

(2) Assoc. Prof., Agr. Eng., Fac. of Agr. Eng., AL-Azhar Univ.

(3) Assoc. lect., Agr. Eng., Fac. of Agr. Eng., AL-Azhar Univ. 
Greenhouses used in Egypt on an increasingly large scale for early production of warm season vegetable, fruit and flowers. In Egypt, numbers of greenhouses reached 61921 greenhouses with area reached 6178 feddans, according to (ADG, 2017). A greenhouse allows plants to grow during any season of the year by controlling light intensity, air temperature, moisture levels, and carbon dioxide. The greenhouses are usually covered with a material such as (glass or plastic) that have the ability to transmit light that provides essential energy for plant growth and production (Saleh et al., 2015). Study the some factors affecting temperature decrease inside the greenhouse through the evaporative cooling system by using solar energy. This research aims to the study the some factors affecting temperature decrease inside the greenhouse through the evaporative cooling system by using solar energy.

\section{REVIEW OF LITERATURE}

One of the main objectives of growing crops in a greenhouse is to extend the productive life of plants and to produce yields when this is not feasible in open field agriculture due to extreme ambient conditions. Here, we present the main cooling methods such as ventilation, shading and reflection, and evaporative cooling (Lychnos and Davies, 2012). Liao and Kara (2002) used three different vertical pad thicknesses namely 5,10 , and $15 \mathrm{~cm}$. These pads were made of an industrial material. They found that the thicker the pad is the higher cooling efficiency. Increasing pad thickness from 5, 10, and $15 \mathrm{~cm}$ increases cooling efficiency by about $16 \%, 19 \%$ and $24 \%$ respectively. Tleaf has been shown to decrease with increasing ventilation rate up to $0.5 \mathrm{~m}^{3} / \mathrm{s} . \mathrm{m}^{2}$ under both hot $\left(30{ }^{\circ} \mathrm{C}, 20 \%\right)$ and mild $\left(25^{\circ} \mathrm{C}, 62 \%\right)$ outside conditions (Seginer, 2002). Incrocci et al. (2006) reported that water use rates of the fan pad (corrugated cellulose) could be deduced as 0.0286 and $0.0176 \mathrm{~L} /$ s. $\mathrm{m}^{2}$ for an air speed across the pad of $1.39 \mathrm{~m} / \mathrm{s}$ and water flow rates to the pad of 0.083 and $0.042 \mathrm{~L} / \mathrm{s} . \mathrm{m}^{2}$, respectively. For a lower air speed across the pad $(0.9 \mathrm{~m} / \mathrm{s})$ the water use rates were 37.3 and $17.7 \mathrm{~g} / \mathrm{s} . \mathrm{m}^{2}$ for the same water flow rates of 0.083 and $0.042 \mathrm{~L} / \mathrm{s} . \mathrm{m}^{2}$, respectively. Ahmad and Adel (2013) studied that effect of bulk charcoal as alternative evaporative cooling pad material. Three using bulk densities for charcoals ( $200.14,206.22$ and $209.58 \mathrm{~kg} / \mathrm{m}^{3}$ ), the water flow rates 
were $0.6,0.19$ and $0.421 \mathrm{~kg} / \mathrm{s}$ and air flows were $0.47,1.38$, and $2.28 \mathrm{~m}$ /s. The cooling efficiency and relative humidity difference were evaluated. The results show that the best average cooling efficiency in $209.58 \mathrm{~kg} / \mathrm{m}^{3}$ charcoal's bulk density at $70 \%$, with $1.38 \mathrm{~m} / \mathrm{s}$ air velocity and $0.19 \mathrm{~kg} / \mathrm{s}$ water flows for each square meter of pad. Antonio et al. (2014) indicated that cellulose pads, four different water flows were tested. These were both below and above the minimum $6.2 \mathrm{~L} / \mathrm{min} \cdot \mathrm{m}$ recommended by (ASABE) for vertical corrugated cellulose pads of 100 $\mathrm{mm}$ thickness. The flows for each replication were: 5, 6.6, 8.3 and 10 $\mathrm{L} / \mathrm{min}$ per linear meter of pad mounted vertically, and when expressed as flow per unit of contact surface $(\mathrm{m} 2)$ of the pad they become 0.128 , $0.171,0.214$ and $0.256 \mathrm{~L} / \mathrm{s} \cdot \mathrm{m}^{2}$, respectively. Abou Karima (1992) reported that the average daily solar energy incident on a horizontal surface in clear sky varies from 6 to $8 \mathrm{~kW} . \mathrm{h} / \mathrm{m}^{2}$, and the yearly mean sunshine duration is about $3000 \mathrm{~h}$ which are a reasonable amount to drive the solar refrigeration system in Egypt. Pridasawas and Lundqvist (2003) said that solar cooling technologies are mainly classified into two main groups depending on the energy supply: a thermal work driven system and electricity (Photovoltaic) driven system. Each group can be classified as the following. Al-Shamiry et al. (2007) studied that design and development of a photovoltaic power system for tropical Greenhouse cooling. The load consists of two fans with total power $400 \mathrm{~W}$, each fan $200 \mathrm{~W}$ and $240 \mathrm{~V} \mathrm{AC}$. The total average daily load is $2.000 \mathrm{kWh} /$ day. Fan consumption at $260 \mathrm{~W}$ and at $240 \mathrm{~V}$ AC through an inverter would require $21.7 \mathrm{Amps} / \mathrm{Hour}$ at $12 \mathrm{~V} \mathrm{DC}$ load demand with a daily operation of 5 Hours (11:00-16:00) and 3 days autonomy. The total load demand is 217 Amps. Rjibi et al. (2016) mentioned that solid desiccant systems are of potential interest as a means of cooling greenhouses to temperatures below those achieved by conventional means. This article aims also to gain knowledge about the performance of desiccant cooling systems coupled to the greenhouse located in Tunisia. The results show an improvement inside greenhouse climate for summer period, with satisfactory thermal comfort of the plants. Liao and Kara (2002) studied three different vertical pad thicknesses namely 5, 10, and $15 \mathrm{~cm}$. these 
pads were made of an industrial material. They found that the thicker the pad is the higher the cooling efficiency.

\section{MATERIALS AND METHODS}

The main objective of the present work is to study the factors affecting cooling in greenhouses by using solar energy. To achieve this aim, the structures of two greenhouses (natural ventilation greenhouse (G1) and cooling greenhouse using solar energy (G2)). The experiments were carried out in the premises of an open roof (third floor) of Faculty of Agriculture Engineering, Al- Azhar University, Nasr City, Cairo Egypt (Latitude angle of $30^{\circ} 02^{\prime} 30^{\prime \prime} \mathrm{N}$, Longitude angle of $31^{\circ} 14^{\prime} 07^{\prime \prime} \mathrm{E}$, and mean altitude above sea level of $18 \mathrm{~m}$ ). The experiments were carried out during two season of 2017/2018.

\section{Greenhouses}

Two similar gable-span form of greenhouses were designed, constructed and operated during this study. The geometric characteristics of the used gable greenhouse were as follows: eaves height $2.60 \mathrm{~m}$, gable height 0.6 $\mathrm{m}$, rafter angle $25^{\circ}$, total width $2.0 \mathrm{~m}$, total length $3.0 \mathrm{~m}$ and floor surface area $6 \mathrm{~m}^{2}$ as shown in Fig. (1). The desiccant cooling system contains principally of three units: regeneration heat source (solar collector), the dehumidifier (desiccant material) and the evaporative cooling. The regeneration heat unit contains, principally of two components and solar collector. The solar collector was made of a wooden box having gross dimensions of $120 \mathrm{~cm}$ long, $80 \mathrm{~cm}$ width. The walls and bottom were constructed of wooden panels ( $1 \mathrm{~cm}$ thick), a wooden frame with a cross section of $(10 \times 5) \mathrm{cm}^{2}$ connected to the flat plate collector, the absorber plate was made of light-gauge steel sheet of $0.05 \mathrm{~cm}$ thick and the space between the bottom and the flat plate collector was insulated by a foam layer of ( $3 \mathrm{~cm}$ thick), this box (collector) was painted from inside by a blackboard paint mixed with $50 \%$ by weight of a talc powder (too fine zinc oxide, nontraditional paint). The rotary desiccant wheel was silica gel ( $\mathrm{SiO} 2)$ which installed by frame of wood of $90 \mathrm{~cm}$ outside diameter, $80 \mathrm{~cm}$ internal diameter and $8 \mathrm{~cm}$ thickness. The desiccant wheel was divided in to two parts. The first part was the regeneration part that equals $50 \%$ of the total surface area. The second part was the absorption part that equals $50 \%$ of the total surface area. The evaporative cooling unit consists of fan, pad and water cycle. 


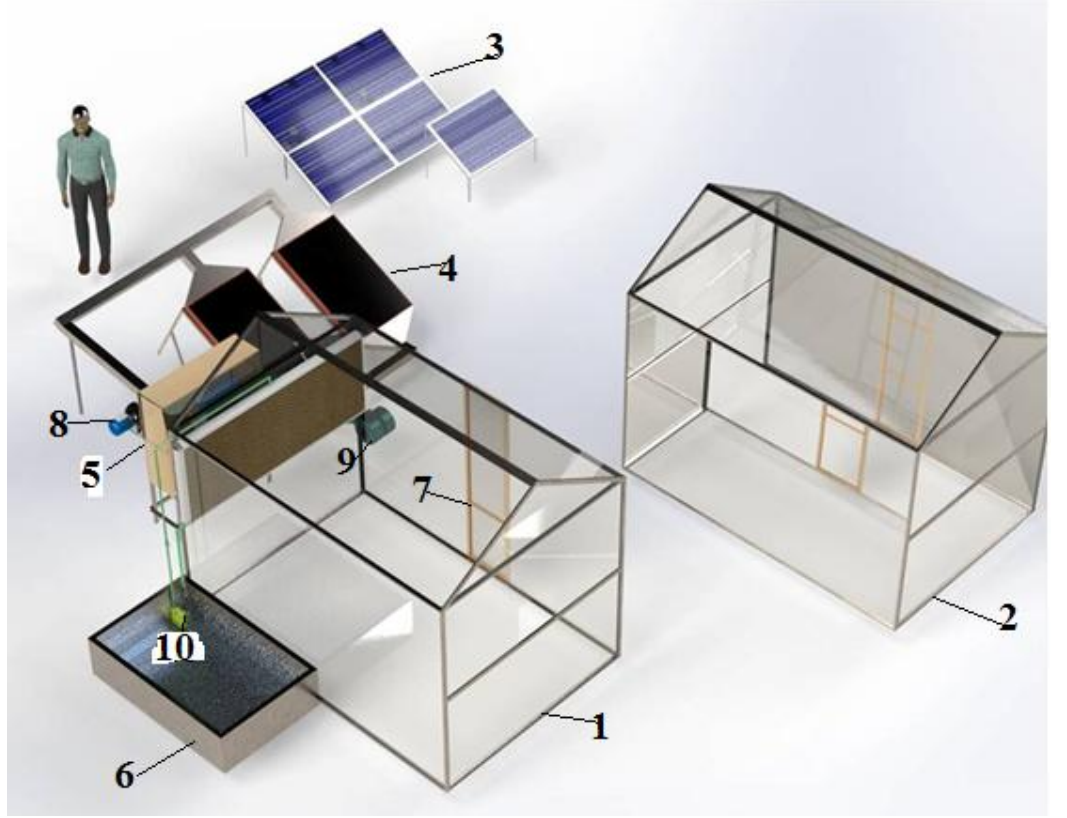

1- G2

2- G1

3- Photovoltaic solar panels

4- Solar collector

5- Desiccant wheel

6- Water tank

7- Door greenhouse

8- Motor

9- Air blower

10- Water pump

Fig. (1): Schematic diagram of greenhouses.

\section{Solar power unit}

The solar power unit was used to generate the desired electricity to cooling units. System configuration: The PV system included five photovoltaic solar Panels, one inverter and two battery banks.

\section{3- The principle of system}

The desiccant evaporative cooling system contains principally three components: regeneration heat source, the dehumidifier (desiccant material), and the cooling unit, Fig. (2). The principle of the system is simple warm and humid air (A) passes through the desiccant wheel and is dehumidified by adsorption of water (B). Its temperature increases and humidity ratio decreases. Then its temperature is lowered in the evaporative cooling (C). Then air is heated by solar energy to regenerate the desiccant wheel $(\mathrm{F})$.

\section{Measurement instruments}

Air velocity device (Anemometer), solar intensity device, a digital AVO meter, digital photo tachometer and data recording unit.

\section{The variable of the study were:}

1. Two pad materials: cellulose and palm fiber 
2. For each material three different air velocity which measured at wheel face were used. These the air velocities were 1,2 and $3 \mathrm{~m} / \mathrm{s}$.

3. Three water flow rats of 10,15 and $20 \mathrm{~L} / \mathrm{min}$ were used on each pad. The combination resulting from the previous variables were given 18 treatments.

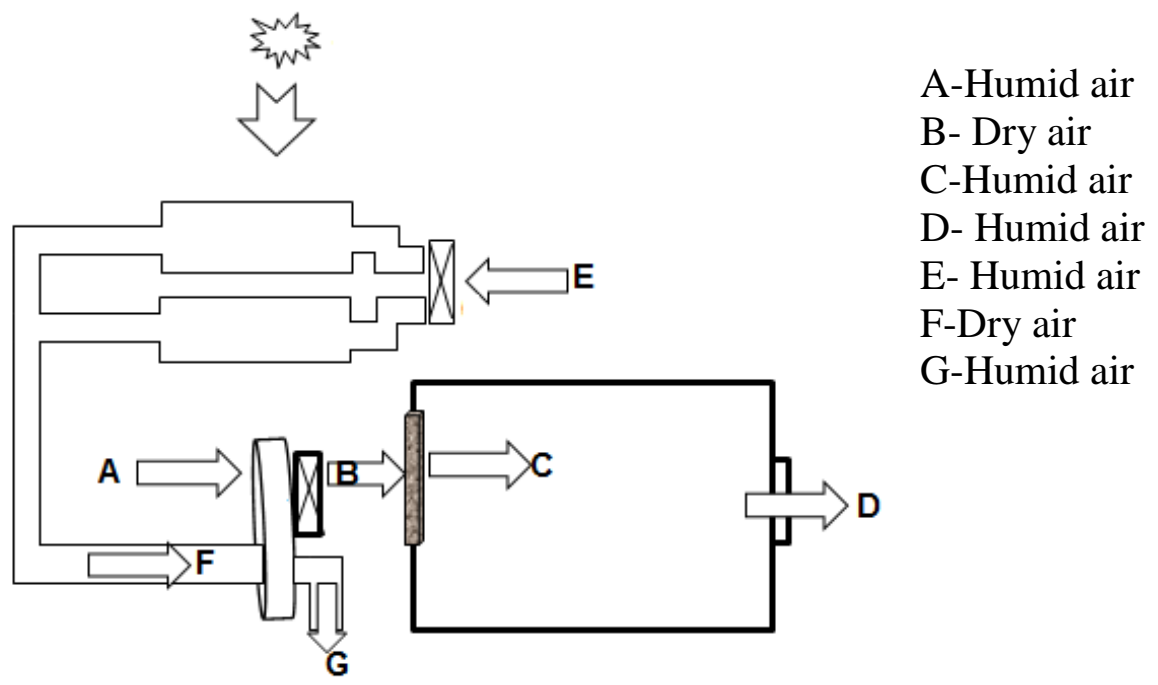

Fig. (2): Schematic the principle of the system.

\section{Measurements}

The experiments were carried out in the premises of an open roof (third floor) of Faculty of Agriculture Engineering, Al- Azhar University, Nasr City, Cairo Egypt it started April on 2017 and ended August on 2018.

\section{Water flow rate}

The water flow rate was controlled on pad by using a valve. To determine the water flow rate, a scaling cylinder and a stop watch were used. The water flow rate was calculated according to the following equation.

$\mathrm{Q}_{\mathrm{w}}=\mathrm{V}_{\mathrm{w}} / \mathrm{t}_{\mathrm{w}}$

Where: $\mathrm{Q}_{\mathrm{w}}$ : Water flow rate, $(\mathrm{L} / \mathrm{min}) ; \mathrm{V}_{\mathrm{w}}$ : Water volume, $(\mathrm{L})$; and $\mathrm{t}_{\mathrm{w}}$ : Time of water flow in graduated cylinder, (min).

Where: $\rho b$ : Pad bulk density "40 kg / $\mathrm{m}^{3} ;$ Mp : pad mass, (kg); V : pad volume, $\left(\mathrm{m}^{3}\right)$; Ap : pad area, $\left(\mathrm{m}^{2}\right)$; and $\mathrm{d}$ : pad thickness, $(\mathrm{m})$.

\section{Air velocity at desiccant wheel face}

The air velocity, which measured at wheel face was recorded at five different position. The air velocity value was the mean of the recorded 
five values of different positions, the air velocity was measured inside the greenhouse by an Anemometer as shown in the following Fig. (3).

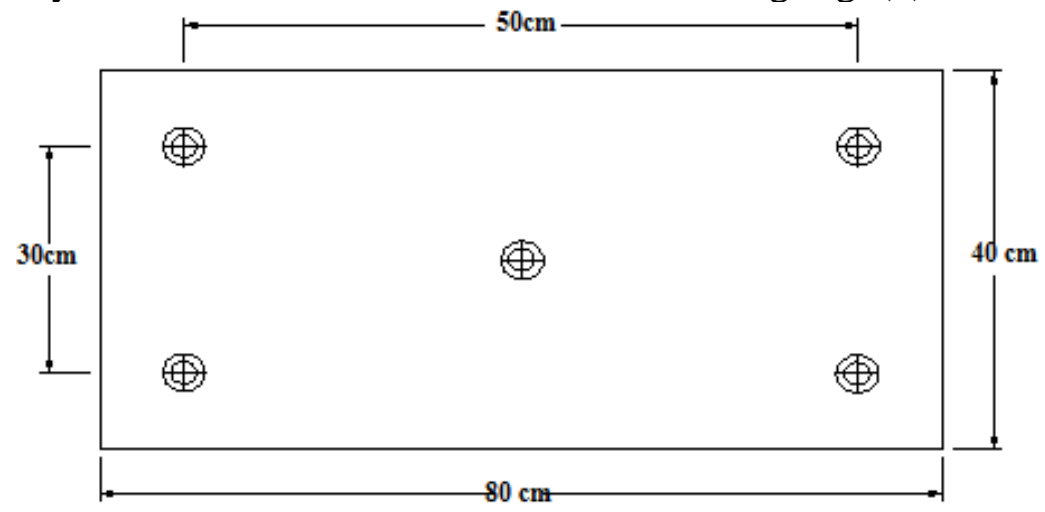

Fig. (3): Positions of the measurement air velocity at desiccant wheel face.

\section{Measuring temperature and humidity}

The dry temperature was measured at nine different positions inside each greenhouse bat, the humidity was measured at three different positions, the dry temperature and humidity were measured outside greenhouse, the dry temperature was measured inside each solar collector, the dry temperature and humidity were measured at three different points inside positions a rotary desiccant wheel.

\section{Wet air temperature and specific humidity}

The wet air temperature and specific humidity were determined in terms of relative humidity and dry temperatures as inputs pulse to a computer program depending on psychometric relationships; that computer program called as "CYT-Soft psychometric".

\section{Estimated factors}

The greenhouses were cooled by using solar energy to decrees the inside temperature during sunny days and supplies carbon dioxide, which is vital to the plants' photosynthesis. In addition to removes warm air and replace it with cool air.

\section{Cooling efficiency}

Saturation efficiency was defined as the ratio of the temperature drop provided by the system to the difference between dray and wet 
temperature, of ambient environment or wet bulb depression according to (Ashrae, 1983).

$$
\boldsymbol{\eta}=\frac{\mathbf{T}_{\mathbf{0}}-\mathbf{T}_{\mathbf{i}}}{\mathbf{T}_{\mathbf{0}}-\mathbf{T}_{\mathbf{w}}}
$$

Where: $\eta$ : Evaporative cooling efficiency, (\%); $\mathrm{T}_{\mathrm{o}}$ : The outer dry temperature at the pad face, $\left({ }^{\circ} \mathrm{C}\right)$; Ti: The inner temperature at the pad face, $\left({ }^{\circ} \mathrm{C}\right)$; and $\mathrm{T}_{\mathrm{w}}$ : Wet-bulb temperature of outside air, $\left({ }^{\circ} \mathrm{C}\right)$.

\section{RESULTS AND DISCUSSION}

\section{Outside and inside temperature patterns}

Air temperature inside the greenhouse is considered as a very important environmental parameter affecting plant growth. Figures $(4,5)$ show the relation between time $(\mathrm{h})$, outer and inner temperature $\left({ }^{\circ} \mathrm{C}\right)$ of greenhouses (G1, G2) when the two pad materials of cellulose and palm fiber were used at three different air velocities which was measured at desiccant wheel face of $(1,2$ and $3 \mathrm{~m} / \mathrm{s})$ and three different water flow rates on pad of $(10,15$ and $20 \mathrm{~L} / \mathrm{min})$. As expected, the air temperature at pad face was lower than the temperature at mid distance of the greenhouse. Temperature at the mid distance of the greenhouse was lower than the temperature at the end of the greenhouse. Generally, all the temperature degrees inside the cooling greenhouse were lower than the temperature degrees outside the cooling greenhouse. Generally, the temperature degrees during afternoon period (11:00 to 14:00) were higher than the temperature degrees of other periods through the day, the temperature values inside the greenhouse were low at the pad but it started to increase gradually from the pad to the end greenhouse for all the experiments. The outer temperature average of the greenhouses was $31.0{ }^{\circ} \mathrm{C}$ through the experiments and the inner temperature average of the greenhouses (G1) and (G2) were 36.4 and $24.5^{\circ} \mathrm{C}$, respectively. The lowest temperature of $21.3{ }^{\circ} \mathrm{C}$ was inside the greenhouse (G2) when temperature of $30.6{ }^{\circ} \mathrm{C}$ was outside, while temperature of $35.8{ }^{\circ} \mathrm{C}$ was inside the greenhouse (G1). The lowest temperature was achieved when the cellulose pad material was used at air velocity which was measured at desiccant wheel face of 2 $\mathrm{m} / \mathrm{s}$ and water flow rate on pad of $20 \mathrm{~L} / \mathrm{min}$. The highest temperature of $28.1^{\circ} \mathrm{C}$ was inside the greenhouse (G2) when temperature of $33.8{ }^{\circ} \mathrm{C}$ was 
outside, while temperature of $39.9{ }^{\circ} \mathrm{C}$ was inside the greenhouse (G1). The highest temperature was achieved when the palm fiber pad material was used at air velocity which was measured at desiccant wheel face of 1 $\mathrm{m} / \mathrm{s}$ and water flow rate on pad of $20 \mathrm{~L} / \mathrm{min}$. For the cellulose pad material, the lowest temperature of $21.3{ }^{\circ} \mathrm{C}$ was inside the greenhouse (G2) when temperature of $30.6{ }^{\circ} \mathrm{C}$ was outside, while temperature of 35.8 ${ }^{\circ} \mathrm{C}$ was inside the greenhouse (G1),

$1 \mathrm{~m} / \mathrm{s}$

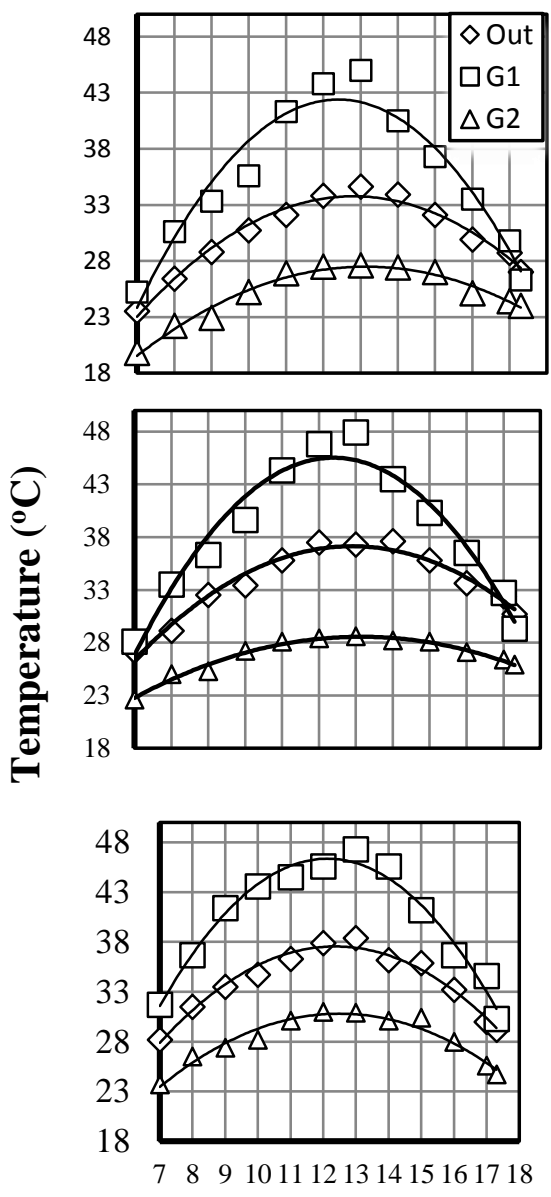

$2 \mathrm{~m} / \mathrm{s}$
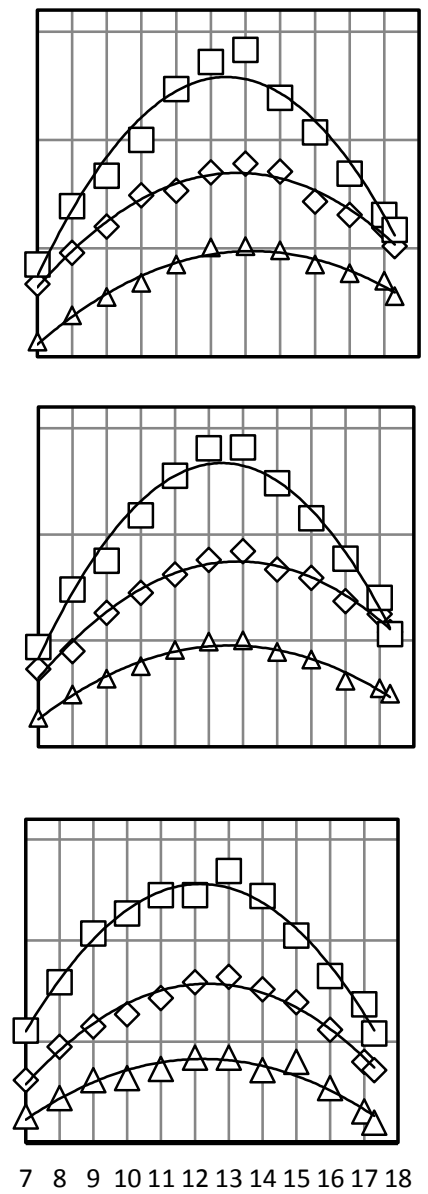

$3 \mathbf{~ m} / \mathbf{s}$

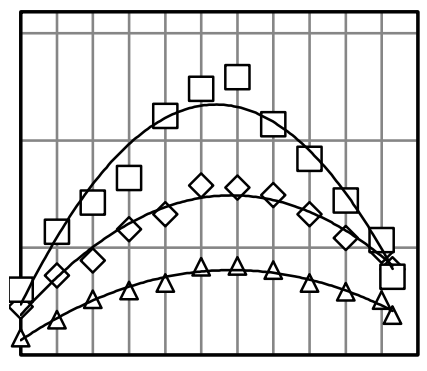

롱

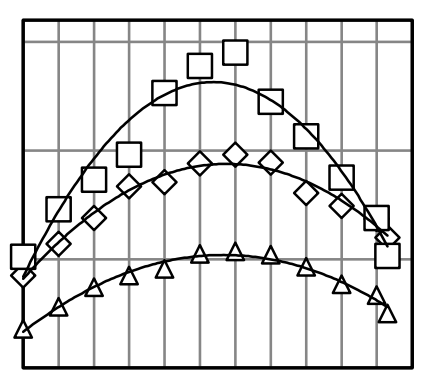

$\frac{3}{3}$

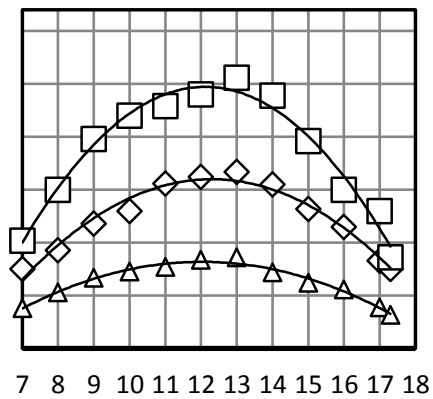

ํㅗㅇ

Time (h)

Fig.(4): The relation between time $(\mathrm{h})$, outer and inner temperature $\left({ }^{\circ} \mathrm{C}\right)$ at air velocities which was measured at desiccant wheel face $(\mathrm{m} / \mathrm{s})$, water flow rates on pad (L/min) and palm fiber material for G1 and G2. 

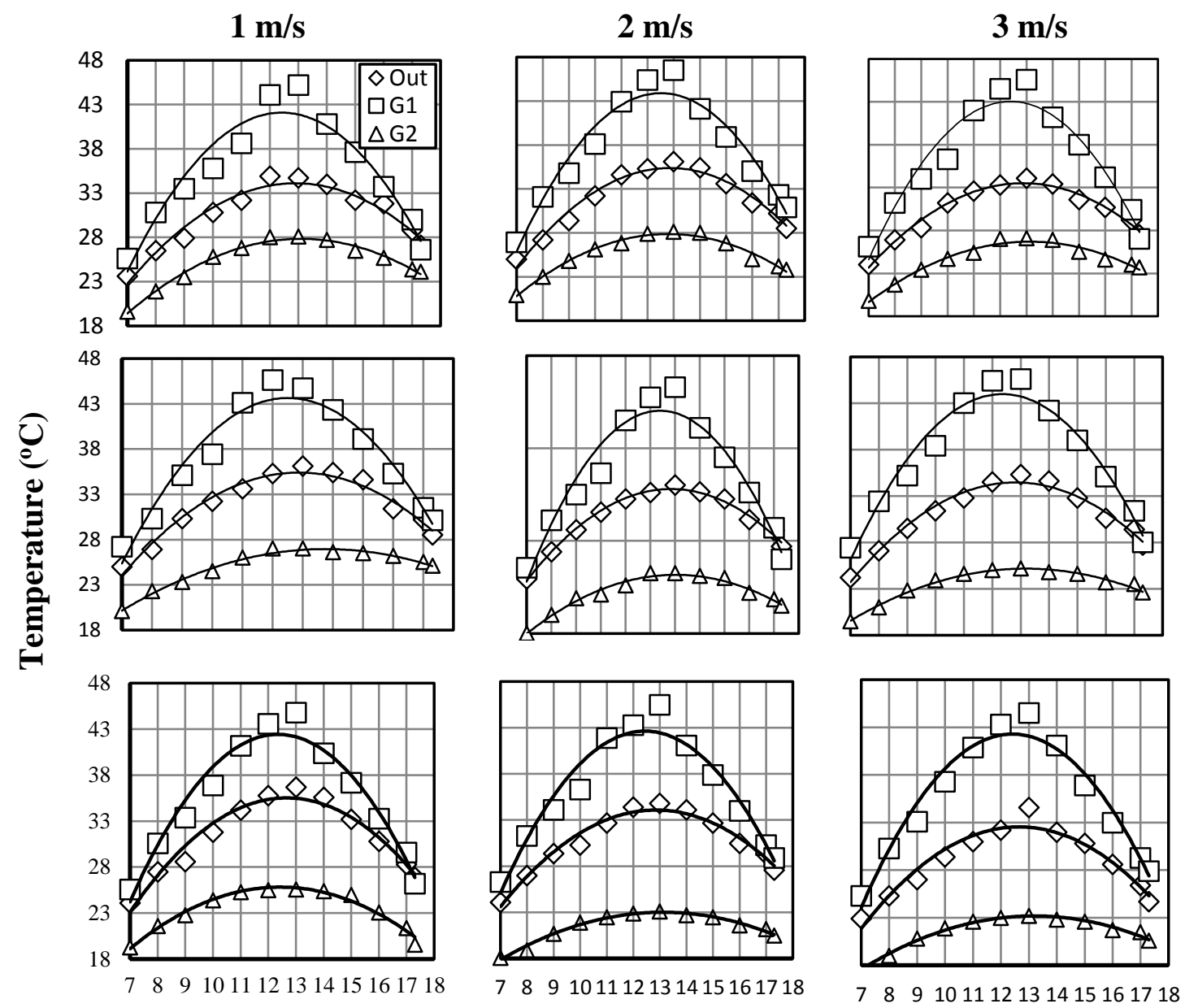

$\frac{\Xi}{\text { Bn }}$

\section{Time (h)}

Fig. (5): The relation between time $(\mathrm{h})$, outer and inner temperature $\left({ }^{\circ} \mathrm{C}\right)$ at air velocities which was measured at desiccant wheel face $(\mathrm{m} / \mathrm{s})$, water flow rates on $\mathrm{pad}(\mathrm{L} / \mathrm{min})$ and cellulose material for G1 and G2.

The lowest temperature was at air velocity which was measured at desiccant wheel face of $2 \mathrm{~m} / \mathrm{s}$ and water flow rate on pad of $20 \mathrm{~L} / \mathrm{min}$. On the other hand the highest temperature of $25.5{ }^{\circ} \mathrm{C}$ was inside the greenhouse (G2) when temperature of $31.6{ }^{\circ} \mathrm{C}$ was outside, while temperature of $37.0{ }^{\circ} \mathrm{C}$ was inside the greenhouse (G1), The highest temperature was at air velocity which was measured at desiccant wheel face of $2 \mathrm{~m} / \mathrm{s}$ and water flow rate on pad of $10 \mathrm{~L} / \mathrm{min}$. For the palm fiber pad material, the lowest temperature of $23.7^{\circ} \mathrm{C}$ was inside the greenhouse 
(G2) when temperature of $29.1{ }^{\circ} \mathrm{C}$ was outside, while temperature of $34.1^{\circ} \mathrm{C}$ was inside the greenhouse (G1), The lowest temperature was at air velocity which was measured at desiccant wheel face of $3 \mathrm{~m} / \mathrm{s}$ and water flow rate on pad of $10 \mathrm{~L} / \mathrm{min}$.

On the other hand the highest temperature of $28.1{ }^{\circ} \mathrm{C}$ was inside the greenhouse $(\mathrm{G} 2)$ when temperature of $33.8^{\circ} \mathrm{C}$ was outside, while temperature of $39.9{ }^{\circ} \mathrm{C}$ was inside the greenhouse (G1), The highest temperature was at air velocity which was measured at desiccant wheel face of $2 \mathrm{~m} / \mathrm{s}$ and water flow rate on pad of $10 \mathrm{~L} / \mathrm{min}$. Generally, lowest temperature was inside when the cellulose pad material was used at air velocity which was measured at desiccant wheel face of $2 \mathrm{~m} / \mathrm{s}$ and water flow rate on pad of $20 \mathrm{~L} / \mathrm{min}$.

\section{Cooling efficiency}

Fig. (6) show the relation between time (h) and cooling efficiency (\%) at different wheel face air velocities and water flow rates on pads. Lowest average value of inner cooling efficiency was $52.3 \%$ at air velocity which was measured at desiccant wheel face of $3 \mathrm{~m} / \mathrm{s}$ and water flow rate on pad of $10 \mathrm{~L} / \mathrm{min}$ for palm fiber pad, while the highest average value of inner cooling efficiency was $65.3 \%$ at air velocity which was measured at desiccant wheel face of $2 \mathrm{~m} / \mathrm{s}$ and water flow rate on pad of $20 \mathrm{~L} / \mathrm{min}$ for the same previous pad. On the other hand, the lowest average value of inner cooling efficiency was $58.3 \%$ at air velocity which was measured at desiccant wheel face of $3 \mathrm{~m} / \mathrm{s}$ and water flow rate on pad of $10 \mathrm{~L} / \mathrm{min}$ for cellulose pad, while the highest average value of inner cooling efficiency was $79.5 \%$ at air velocity which was measured at desiccant wheel face of $2 \mathrm{~m} / \mathrm{s}$ and water flow rate on pad of $20 \mathrm{~L} / \mathrm{min}$ for the same pad material. Form the previous illustration, the pad of cellulose gave the highest inner cooling efficiency when the measured air velocity which was measured at desiccant wheel face was $2 \mathrm{~m} / \mathrm{s}$ and water flow rate on pad was $20 \mathrm{~L} / \mathrm{min}$ at outer temperature of $30.6{ }^{\circ} \mathrm{C}$ and relative humidity of $41.2 \%$.

\section{Effect of study factors on cooling efficiency}

\section{Effect of wheel face air velocity on cooling efficiency}

Fig. (7) indicated the relation between wheel face air velocity and cooling efficiency $(\eta)$ at three different water flow rates and two different pad materials (palm fiber and cellulose). 
Palm fiber

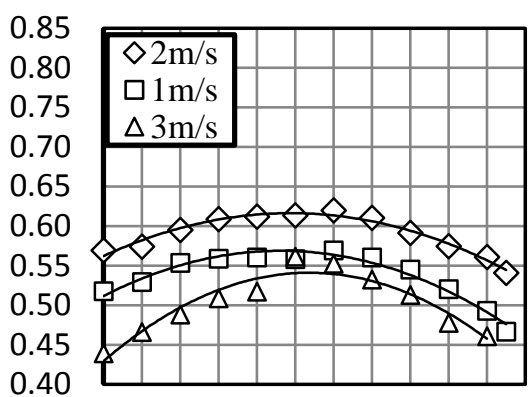

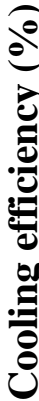

0.85

0.80

0.75

0.70

0.65

0.60

0.55

0.50

0.45

0.40

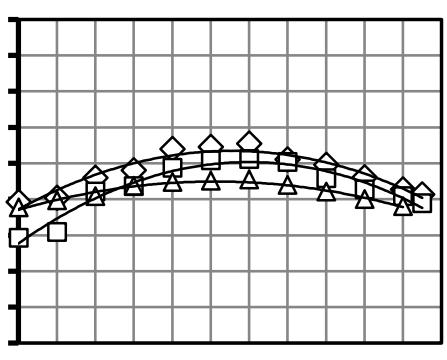

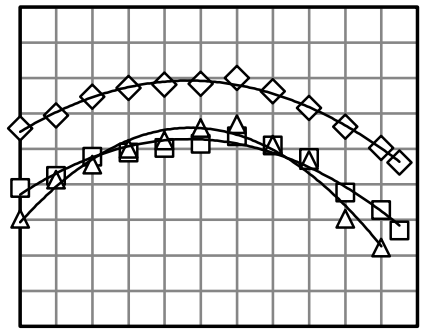

鲁
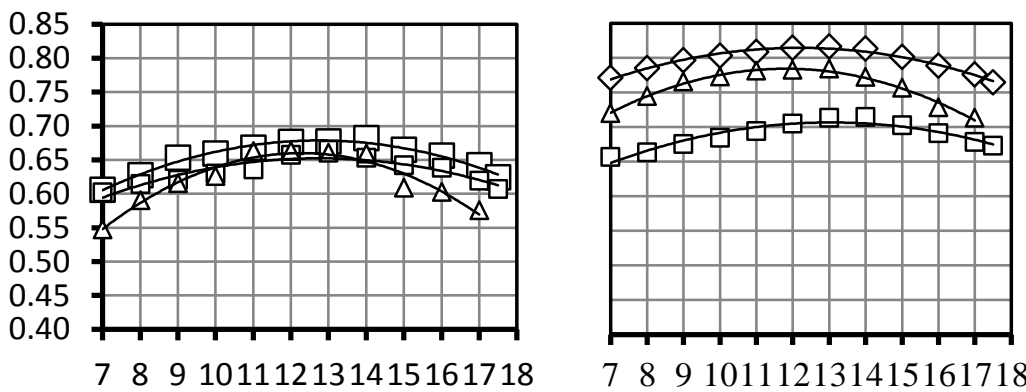

Time (h)

Fig. (6): The relation between time (h) and cooling efficiency (\%) at different at air velocities which was measured at desiccant wheel face $(\mathrm{m} / \mathrm{s})$ and water flow rates on $\operatorname{pad}(\mathrm{L} / \mathrm{min})$ for different pad materials.

Generally, air velocity which was measured at desiccant wheel face increased the cooling efficiency from $1 \mathrm{~m} / \mathrm{s}$ to $2 \mathrm{~m} / \mathrm{s}$ after that the cooling efficiency was decreased at $3 \mathrm{~m} / \mathrm{s}$ and this may be due to attributed difference was in outside temperature values and outside relative humidity values, measurement air velocity on wheel face not pad face and high air velocity reduces its saturation when it traffic through pad. The achieved statistical analysis by using ANOVA test, it cleared that the air 
velocity which was measured at desiccant wheel face had no significant effect on cooling efficiency.

\section{Effect of water flow rates on pad on cooling efficiency}

Fig. (7) illustrated the relation between water flow rates on $\mathrm{pad}(\mathbf{L} / \mathbf{m i n})$ and cooling efficiency (\%) at three different air velocities which was measured at desiccant wheel and two different pad materials (palm fiber and cellulose).

$\boldsymbol{v}_{\boldsymbol{a}}(\mathrm{m} / \mathrm{s})$

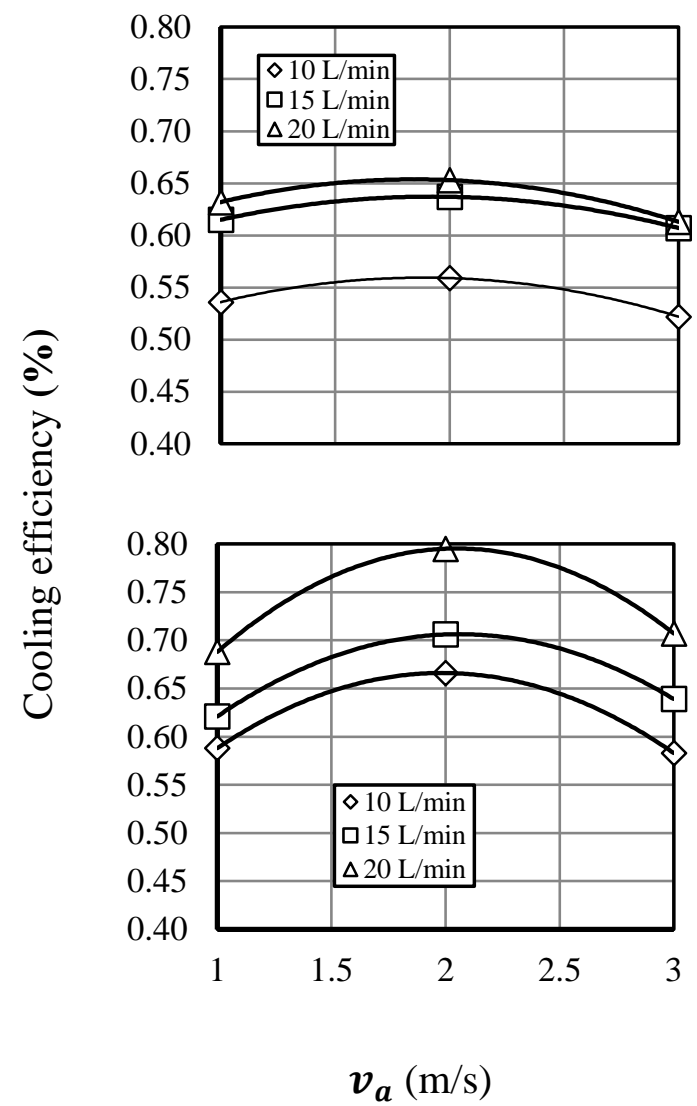

$Q_{w}(\mathbf{L} / \mathbf{m i n})$

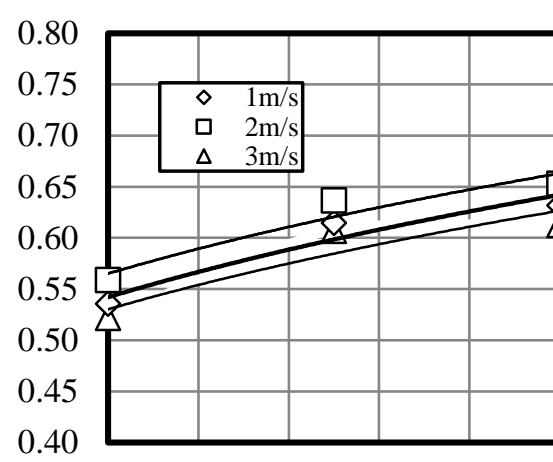

离

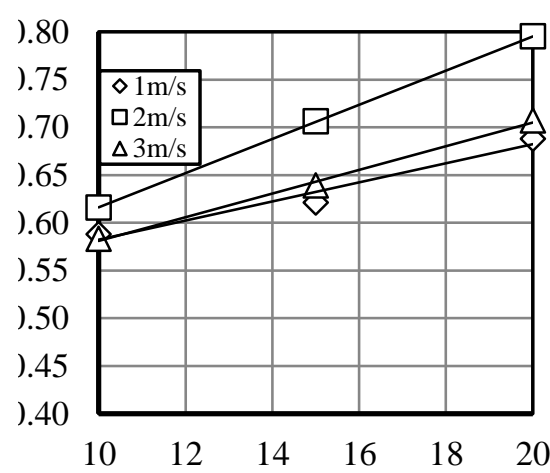

$Q_{w}(\mathrm{~L} / \mathrm{min})$

Fig. (7): The relation between air velocity which was measured at desiccant wheel face which was measured at desiccant wheel, water flow rate on pad and cooling efficiency.

The obtained data showed that the cooling efficiency $(\eta)$ increase by increasing water flow rates for the both two different pad materials (palm 
fiber and cellulose). The achieved Statistical analysis by using ANOVA test, indicated that the water flow rates on pad had a significant effect on cooling efficiency and this due to low water conservation efficiency of fiber palm pad.

\section{Effect of pad materials on cooling efficiency}

The achieved Statistical analysis by using ANOVA test, indicated that the pad materials had a significant effect on cooling efficiency, this due to low water conservation efficiency of fiber palm pad and non regularity of distribution of the fiber palm inside the pad.

\section{REFERENCES}

Abou Karima, (1992). Design And Testing of A Refrigeration System Utilizing Solar Energy, M.Sc., Faculty of Agriculture, University of Alexandria, 4- 7.

ADG (Agriculture Directorates of Governorates, Vegetable Affairs Sector) (2017). Quarterly bulletin of statistics.

Ahmad, K. and B. Adel, (2013). The Evaluation of Bulk Charcoal as Greenhouse Evaporative Cooling Pad, Agric. Eng. Int., 15(2):188 198. http://www.cigrjournal.org.

Al-Shamiry, F. M.; D. Ahmad and A. R. Sharif, (2007). design and development of a photovoltaic power system for tropical greenhouse cooling, American Journal of Applied Sciences, 4 (6): 386-389.

Antonio, F.; L. v. Diego and P. Araceli, (2014) Energy Efficiency in Greenhouse Evaporative Cooling, Techniques: Cooling Boxes versus Cellulose Pads, Energies, 7:1427-1447.

https://www.researchgate.net/publication/229226589.

Ashrae, (1983). Evaporative air-cooling equipment. Chapter 4. Equipment Handbook. American Society of Heating, Refrigeration and Air-Conditioning Engineers. Atlanta, Georgia, USA.

Incrocci, L.; F. Malorgio; A.D. Bartola and A. Pardossi, (2006). The influence of drip irrigation or subirrigation on tomato grown in closed- 
loop substrate culture with saline water, Scientia horticulturae, 107:365372 .

Liao, C. M. and H. Kara, (2002). Wind tunnel modeling the system performance of alternative evaporative cooling pads in taiwan region. Building and Environment, 37: 177-187.

http://sci-hub.cc/10.1016/s0360-1323(00)00098-6.

Lychnos, G. and P.A. Davies, (2012). Modeling and experimental verification of a solar-powered liquid desiccant cooling system for greenhouse food production in hot climates, Energy, 40: 116-130.

Pridasawas, W. and P. Lundqvist, (2003). Technical Options for a Solar-driven Cooling system, Proceeding of the International Solar Energy Congress, Gothenburg, 289-297.

Saleh, D. G. A.; M. H. Hatem; E. A. Mostafa and F. S. E. Kassim, (2015). Environmental study to improve the performance of grafting mango seedlings using different cover materials for greenhouses, Misr J. Ag. Eng., 32 (1): 281 - 294.

Seginer, I., (2002). The role of transpirational cooling in the design of greenhouse ventilation, Acta .Hort., 578:55-61.

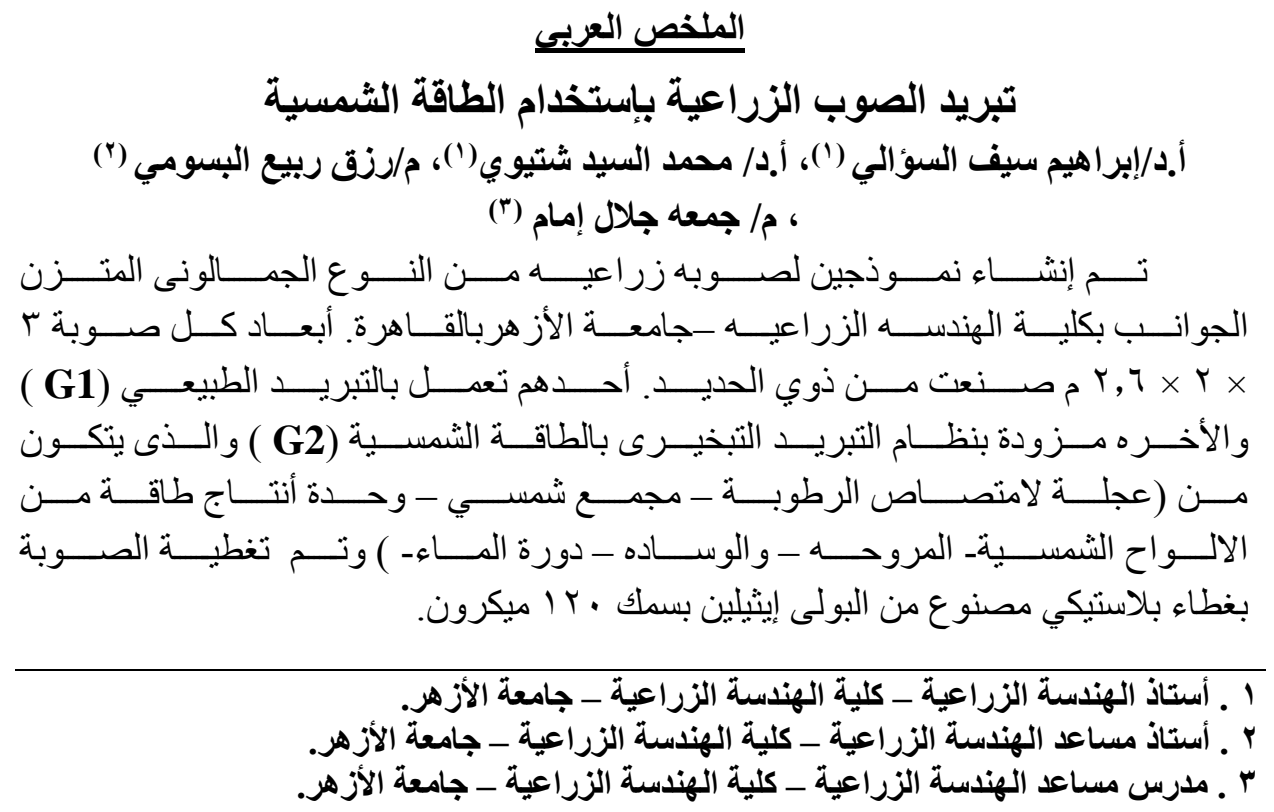




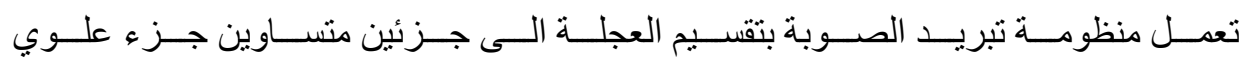

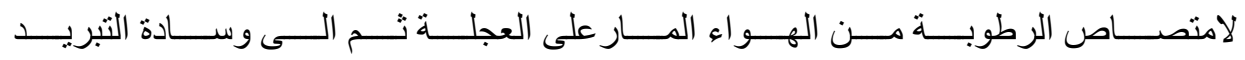

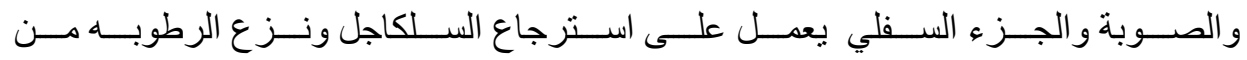

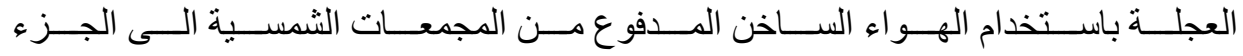

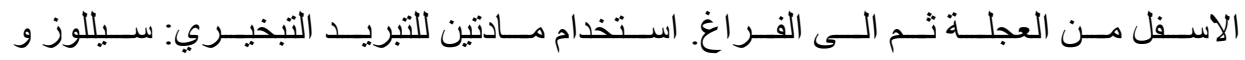

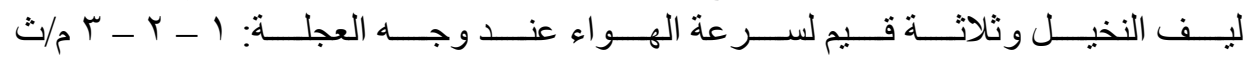

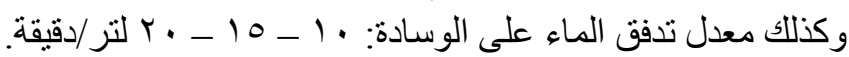

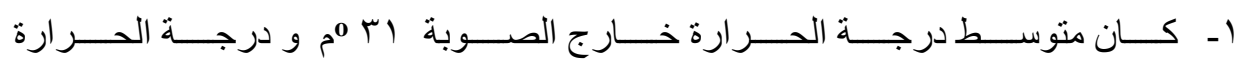

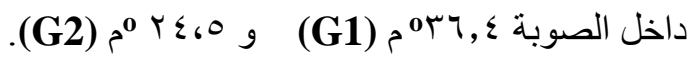

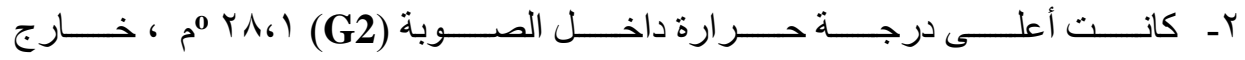

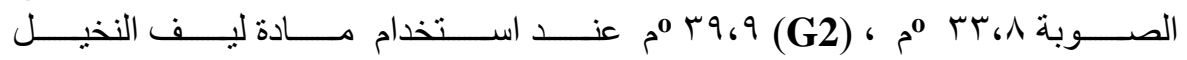

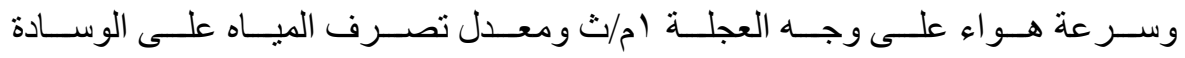
•

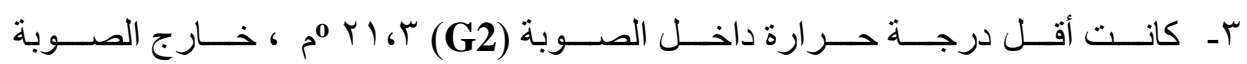

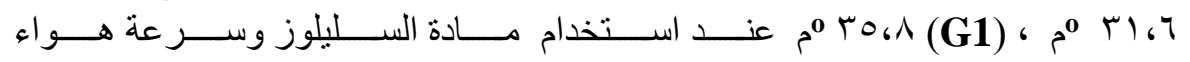

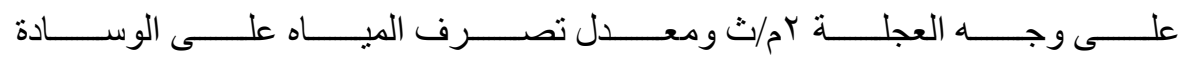
.

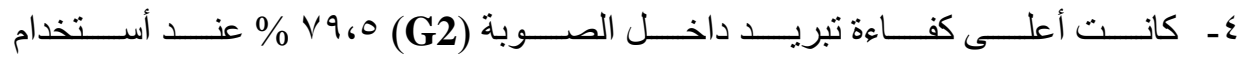

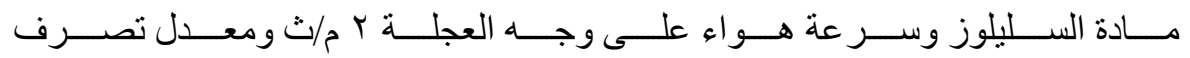

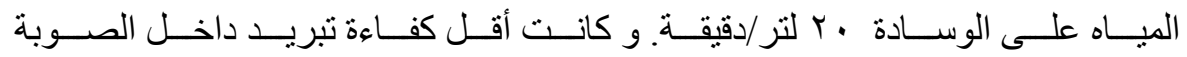
\% Or.r (G2) العجلة بام/ث ومعدل تصرف المياه على الوسادة ـ التر/دقيقة. 